\title{
The Assesment of Physical Variables of the Soil Quality Index in the Coal Mine Spoil
}

\author{
Antoni Grzywna ${ }^{1 *}$, Małgorzata Ciosmak ${ }^{2}$ \\ 1 University of Life Science in Lublin, Lublin University of Technology \\ * Corresponding author's email: antoni.grzywna@up.lublin.pl
}

\begin{abstract}
This paper aimed to evaluate the physical properties of the soils on the slope of the spoil heap of the coal mine in Bogdanka based on literature and the authors' opinion. The field soil tests were carried out in the agricultural season of 2018 in the coal mine waste dump. The main purpose was to develop and apply the soil physical quality index. For the calculation of the SPQI used nine soil physical properties: texture, bulk density, MWD, AWC, K, POR, PAW, S, StI. The paper used a system for assessing the physical parameters of soil within the range from 0 to 4 . On the basis of the research, it was found that the best parameters of soil quality occurred in the surface horizons and increased with depth. The SPQI value calculated for the $0-60 \mathrm{~cm}$ Technosol layer was 0.51 , which indicates good soil parameters.
\end{abstract}

Keywords: soil quality physical index, coal mine soil heap, Technosol

\section{INTRODUCTION}

The soil quality is defined as the capacity of a specific kind of soil to function within natural or managed ecosystem boundaries, to sustain the plant and animal productivity, maintain and enhance the water and air quality, and support human health and habitation (Karlen et al. 2001). It cannot be measured directly, but it can be evaluated indirectly based on the features of the soil itself or on the features of the ecosystem of which the soil forms a part. The assessment of quality makes it possible to record the changes in the status of soil caused by natural factors and human activity. The soil science literature mentions many morphological features as well as physical, chemical, physicochemical and biological properties connected with soil conditions and its functions among the indicators of soil quality and health (Bastida et al. 2008). Depending on the land use type, respective indicators play a larger or a smaller role (Reynolds 2008, Armenise et al. 2013).

The human influence on agricultural land can deteriorate the soil quality, and the soil quality may differ among land uses (Girmay and Singh
2012, Zobeck et al. 2015). The physical condition of soil is understood as all features and properties of soil that result from physical phenomena and that can be measured by means of physical methods. The most important physical properties of soils include: texture, structure, soil density, porosity, compaction, swelling and shrinkage, as well as functional properties: water, air and heat (Cherubin et al. 2016, Dwevedi et al. 2017, Nabayi et al. 2019). Water properties, in particular retention of water used by plants and hydraulic conductivity, determine plant growth, development and harvest conditions (Masto et al. 2008, Drewry et al. 2008, Feiza et al. 2011). Under field conditions, a permanent aggregate structure is a guarantee of the best physical condition of soil. It prevents excessive soil compaction and ensures the right proportion of capillary pores in soil (diameters equivalent to $0.2-20 \mu \mathrm{m}$ ) storing water used by plants and the right proportion of macropores with diameters $>20 \mu \mathrm{m}$ that determine hydraulic conductivity as well as air capacity and permeability (Lipiec et al. 2007, Asensio et al. 2013). In addition, water-stable aggregate structure protects soil from surface crusting, increases 
the infiltration of precipitation water, as well as decreases the rate of run-off and water erosion (Barthes and Roose 2002, Singh and Khera 2009, Asgarzadeh et al. 2010, Masto et al. 2015).

In order to enable the assessment of soil quality, it is necessary to determine the values of the relevant parameters and to assign appropriate indices to them. That is why a systematic approach combining knowledge about soil with the problems of shaping natural resources is needed. A systemic approach is important for the assessment of soil quality, because different interests need to be taken into account when trying to meet different social objectives. A landscape analysis requires basic research and cooperation between researchers, farmers and the municipality. The quality information related to the different soil functions must be readily available. In terms of soil quality, rhis research needs provide evidence that field trials are the only way to obtain the information needed for assessment (Andrews and Carroll 2001, Albaladejo et al. 2013, Zornoza et al. 2015).

The soil quality assessment includes a threestep procedure developed by Andrews et al. (2004) and later used by many researchers. For the interpretation of physical, chemical and biological processes occurring in soils, it is necessary to know the water and air properties of soils (Dexter and Czyż 2007, Zornoza et al. 2007, Imaz et al. 2010, Dwevedi et al. 2017).

This paper aimed to evaluate the physical properties of soils on the slope of spoil heap of the coal mine in Bogdanka based on the literature studies and authors' opinion. The main purpose was developing and applying the soil physical quality index (SPQI). Specific study objectives include assessment of the aggregate composition, water stability of soil aggregates, soil density, total porosity, water capacity, distribution of pores in soil and water retention of Technosol.

\section{STUDY AREA}

The study area covers the industrial soils located in Bogdanka on the coal mine soil heap $\left(51^{\circ} 19^{\prime} 43^{\prime \prime} \mathrm{N}, 23^{\circ} 00^{\prime} 10^{\prime \prime} \mathrm{E} ; 170.00 \mathrm{~m}\right.$ a.s.l.), in eastern Poland (Łęczna commune, Lublin voivodeship). The soil heap was studied due to the physical and chemical properties of rock material and it is unique in Europe. The studied gangue heap is situated in a lowland area with a poorly expressed decline from the north to the south. The subsoil under the heap, at the depth of 40-45 m, is built from Quaternary formations, mainly sand or sand and clay. The heap drainage system consists of surrounding ditches, drainage canal and the River Świnka debouching into the River Wieprz. The above-mentioned gangue heap was built stage by stage between 1981 and 1994 . First, the ground at the projected location of the heap was levelled. Next, as a result of depositing gangue up to a height of 175, 185 and $196 \mathrm{~m}$ above sea level, a two-layer heap was built with a surface area of 38 ha and height of $26 \mathrm{~m}$. The heap with slopes inclined 2:1, comprises homogenous pieces of Carboniferous rocks from mining pits. Most often, these are mixed pieces of clay stone and mudstone (70\%) with intrusions of sandstone and coal slate (30\%). The following parameters of the soil layer for heap reclamation were determined in 1995-99: $0.0-10.0 \mathrm{~cm}$ - topsoil; $10.0-60.0 \mathrm{~cm}$ - technosol (sandy clay); below $60.0 \mathrm{~cm}$ - gangue. The slopes were reclaimed to forest, and mining waste is still stored on the blanket layer (Gazda and Oleszczyński 1988, Turski et al. 1991, Borchulski et al. 1994, Święs and Kwiatkowska-Farbiś 1996).

The site is located in the macro-region of West Polesie (845.3) and in the mesoregion of the Łęczna-Włodawska Plain. In terms of climate, it is characterized by average thermal and precipitation conditions. In the years 1981-2010, the average annual temperature was $8.5^{\circ} \mathrm{C}$, and the sum of precipitation was $616 \mathrm{~mm}$ (Kondracki 2001, Ciosmak et al. 2017).

\section{METHODS}

\section{Soil analysis}

The field soil tests were carried out in the agricultural season of 2018 in the coal mine waste dump. In the field, forty soil test point were dug to a depth of $60 \mathrm{~cm}$. The disturbed soil samples were taken from each genetic horizon in order to determine the soil texture and for the purposes of other laboratory analyses. The undisturbed soil samples were collected from each genetic horizon using Kopecky cylinders (Borek 2019). The soil samples were obtained from depths $0-10,10-20,20-40$, and 40-60 cm. The indicators of soil quality and health include many physical properties of soil (Shukla et al. 
2006, Reynolds et al. 2009, Muršec et al. 2018). Texture is a fundamental physical feature of soil. The soil texture was determined with the aerometric method of Bouyoucose-Casagrande modified by Prószyński. The WRB classification (2014) was used to describe the particle size classes (clay $<0.002 \mathrm{~mm}$, silt $0.05-0.002 \mathrm{~mm}$, sand $2.0-0.05 \mathrm{~mm}$ ). The obtained data was used to calculate water stable aggregates (WSA) and mean weight diameter (MWD). In order to assess the risk of degradation of the structure of arable soils, Pieri (1992) proposed the adoption of the structure stability index (StI) depending on their texture and organic matter content.

Soil bulk density (BD) was measured in Kopecky's cylinders as soil cores weight per volume. Then, the soil mass was determined after drying at $105^{\circ} \mathrm{C}$. On the basis of the $\mathrm{BD}$ value and specific gravity, the physical structure of the soil, soil compaction and porosity were determined (Czyż 2004, Reynolds et al. 2008). Soil porosity is the volume of air zone in relation to the total soil volume (Głąb and Kulig 2008).

The total plant-available water capacity (PAW) of the soil was calculated as the difference at 5 to $15 \mathrm{MPa}$ moisture potentials. The potential available water capacity (AWC) of the soil was calculated as the difference at 0.033 to $1.5 \mathrm{MPa}$ in volumetric water content. PAW and AWC were measured on a pressure plate extractor. Saturation of hydraulic conductivity $(\mathrm{K})$ was determined using the Wita apparatus (Aimrun et al. 2004, Iwanek 2008). Saturation of hydraulic conductivity determines the speed of groundwater flow at the maximum water capacity. The soil physical quality index (index S) was estimated by using van Genuchten model. The estimation of the parameter was carried out using the RETC application, using the percentage of clay, sand, silt (Moncada et al. 2015, Borek 2019).

\section{Soil physical quality index (SPQI) calculations}

The SPQI was assessed by following a threestep procedure: (1) identification of the data set of indicators, (2) indicator interpretation, (3) integration of the all indicator scores into one overall SPQI value (Andrews et al. 2004, Mukhopadhyay et al. 2016).

The SPQI value was estimated following the method based primarily on the literature review and the soil parameters according to the authors opinion'. In this method, the threshold values were given (Amacher and Perry 2007). The parameters soil and associated unit soil index score values are listed in Table 1. The individual index values were then summed up to obtain a total SPQI:

$$
\mathrm{SPQI}=\sum \mathrm{S} / \mathrm{n} * \mathrm{i}
$$

where: $S$ denotes score of soil parameter, $n$ is the number of parameters, $i$ is maximum index

The soil index score values in literature most often range from 0 to 2 or less often from 1 to 5. The paper makes use of a system for the assessment of physical parameters of soil within the range of 0 to 4 . The points scale facilitates precise determination of soil quality. The threshold levels, interpretations, and associated unit less soil index score values are listed in Table 1.

\section{Statistical analysis}

On the basis of all the results of the area or laboratory measurements, mean values and standard

Table 1. Scoring function chart for soil physical quality index (Pieri 1992, Lal 1994, Reynolds 2009, Paluszek 2011, Mukherjee and Lal 2014, Nakajima et al. 2015) - modified

\begin{tabular}{|l|c|c|c|c|c|c|}
\hline \multicolumn{1}{|c|}{ Parameter } & unit & 4 & 3 & 2 & 1 & 0 \\
\hline Texture & - & $\mathrm{L}$ & $\mathrm{Si}, \mathrm{SiL}, \mathrm{SiCL}$ & $\mathrm{CL}, \mathrm{SL}$ & $\mathrm{SiC}, \mathrm{LS}$ & $\mathrm{C}, \mathrm{S}$ \\
\hline $\mathrm{BD}$ & $\mathrm{Mg} \cdot \mathrm{m}^{-3}$ & $<1.2$ & $1.2-1.3$ & $1.3-1.4$ & $1.4-1.5$ & $>1.5$ \\
\hline MWD & $\mathrm{mm}$ & $>2.5$ & $2-2.5$ & $1-2$ & $0.5-1$ & $<0.5$ \\
\hline AWC & $\mathrm{m}^{3} \cdot \mathrm{m}^{-3}$ & $>0.3$ & $0.2-0.3$ & $0.08-0.20$ & $0.02-0.08$ & $<0.02$ \\
\hline $\mathrm{K}$ & ${\mathrm{cm} \cdot \mathrm{d}^{-1}}$ & $>950$ & $300-950$ & $20-300$ & $5-20$ & $<5$ \\
\hline POR & $\%$ & $>40$ & $35-40$ & $30-35$ & $25-30$ & $<25$ \\
\hline PAW & $\mathrm{m}^{3} \cdot \mathrm{m}^{-3}$ & $>0.2$ & $0.15-0.20$ & $0.10-0.15$ & $0.05-0.10$ & $<0.05$ \\
\hline Stl & $\%$ & $>9$ & $7-9$ & $5-7$ & $3-5$ & $<3$ \\
\hline $\mathrm{S}$ & - & $>0.055$ & $0.045-0.055$ & $0.035-0.045$ & $0.020-0.035$ & $<0.02$ \\
\hline
\end{tabular}


deviation were calculated. The significance of differences was analysed for the database thus obtained. The treatment differences were analysed using Tukey's test at significance level of $p<0.05$. Then, using the Shapiro-Wilk test, the normality of the data distribution was checked. The Pearson correlation test was also performed for the physical parameters of the soil. The calculations were carried out using the Statistica PL version 12.5 software package.

\section{RESULTS AND DISCUSSION}

Four genetic horizons were distinguished in the studied soil profiles. The analysed soils are characterized by a high content of clay in the surface horizon of $0-10 \mathrm{~cm}$, while loam dominates in the deeper horizons. Accordingly, the soil texture is heterogeneous. Nevertheless, individual soil properties are characterized by a slight variation in the observed values. The standard deviation of the tested parameters is relatively small. The highest SD was in hydraulic conductivity (K). The sand content in the soil profiles ranged at 20 to $50 \%$, silt content between 10 and $40 \%$, and clay content between 30 and $70 \%$. The average and standard deviation values of nine physical parameters are presented in Table 2.

The mean weight diameter (MWD) is characteristic for sandy clay and amounts to $1.9 \mathrm{~mm}$ for the $0-10 \mathrm{~cm}$ layer and $1.5 \mathrm{~mm}$ for the $10-40 \mathrm{~cm}$ layer.

Bulk density is one of the important physical properties of soil that characterizes soil compaction and can affect the soil water properties. Bulk density (BD) ranged from $1.23 \mathrm{~g} \cdot \mathrm{cm}^{-3}$ to $1.68 \mathrm{~g} \cdot \mathrm{cm}^{-3}$ and usually increased with depth
(Table 2). The lowest BD value was observed in the $0-10 \mathrm{~cm}$ horizon, where the organic carbon content was the highest. However, the highest density was found in the horizon of 40-60 cm, where the clay content was the greatest. The soil bulk density varies widely. The lowest values were observed in the surface horizon and they increased with depth (Hamza and Anderson 2005). As shown in Table 2, the mean value of StI indicates a very high risk of soil degradation (StI $<5 \%$ ) (Reynolds et al. 2009).

Soil porosity (POR) at the level of $0-40 \mathrm{~cm}$ exceeds $40 \%$, which is an optimum value in terms of plant cultivation. Porosity is only lower at the level of $40-60 \mathrm{~cm}$, which is a result of the presence of pieces of clay stone. High soil porosity is connected with low bulk density and specific gravity.

The analyzed soil samples are characterized by a high water content. High water content is one of the basic factors influencing high plant production. The water capacity available for plants is $0.22 \mathrm{~m}^{3} \cdot \mathrm{m}^{-3}$, and the available water capacity is $0.24 \mathrm{~m}^{3} \cdot \mathrm{m}^{-3}$. High water retention capacity in soil will contribute to limiting the effects of climate change (Tárník and Leitmanová 2017). The water capacity of soil is very often related to its granulometric composition, in particular with the participation of clay (Touil et al. 2016).

The variety of factors affecting the conductive properties of soils causes very high spatial and temporal variability of the values obtained (Mohanty and Mousli 2000, Iwanek 2008). Hydraulic conductivity $(K)$ was in the range of $50 \mathrm{~cm} \cdot \mathrm{d}^{-1}$ to $240 \mathrm{~cm} \cdot \mathrm{d}^{-1}$ and predominantly increased with depth (Table 2). The highest porosity was visible in the horizon of $0-10 \mathrm{~cm}$ where the carbon content was the highest. The porosity decreased with

Table 2. Values of the soil physical parameters collected from heap slopes

\begin{tabular}{|c|c|c|c|c|c|c|c|c|c|}
\hline \multirow{2}{*}{$\begin{array}{c}\text { Parameter } \\
\text { Specification }\end{array}$} & \multirow{2}{*}{$\begin{array}{c}\text { Depth } \\
\text { unit }\end{array}$} & \multicolumn{2}{|c|}{$0-10$} & \multicolumn{2}{|c|}{$10-20$} & \multicolumn{2}{|c|}{$20-40$} & \multicolumn{2}{|c|}{$40-60$} \\
\hline & & mean & SD & mean & SD & mean & SD & mean & SD \\
\hline Texture & - & L & & SiL & & SiL & & SiL & \\
\hline $\mathrm{BD}$ & $\mathrm{Mg} \cdot \mathrm{m}^{-3}$ & 1.23 & 0.1 & 1.36 & 0.1 & 1.55 & 0.1 & 1.68 & 0.1 \\
\hline MWD & $\mathrm{mm}$ & 1.7 & 0.6 & 1.5 & 0.3 & 1.5 & 0.3 & 1.4 & 0.2 \\
\hline AWC & $\mathrm{m}^{3} \cdot \mathrm{m}^{-3}$ & 0.2 & 0.06 & 0.24 & 0.04 & 0.23 & 0.02 & 0.17 & 0.05 \\
\hline $\mathrm{K}$ & $\mathrm{cm} \cdot \mathrm{d}^{-1}$ & 240 & 82 & 160 & 61 & 110 & 22 & 50 & 10 \\
\hline POR & $\%$ & 50 & 4.1 & 46 & 3.7 & 44 & 2.1 & 37 & 3.3 \\
\hline PAW & $m^{3} \cdot m^{-3}$ & 0.22 & 0.05 & 0.2 & 0.04 & 0.19 & 0.03 & 0.13 & 0.06 \\
\hline Stl & $\%$ & 2.8 & 0.22 & 4.7 & 0.18 & 3.2 & 0.14 & 1 & 0.1 \\
\hline S & - & 0.04 & 0.007 & 0.046 & 0.006 & 0.017 & 0.004 & 0.027 & 0.005 \\
\hline
\end{tabular}


increasing depth. The range of $\mathrm{K}$ fluctuations can be very wide. The highest values were observed in surface horizons and they decreased with depth (Tárník and Leitmanová 2017).

The highest values of the $\mathrm{S}$ index were recorded at the level of 40-60 cm (>0.04), which indicates a very poor quality of the soil. The lowest values of the $S$ index at the level of $0-10 \mathrm{~cm}$ $(<0.02)$, which indicates good physical quality of the soil. The mean value of the $\mathrm{S}$ index $(0.03)$ indicates high soil quality (Table 2).

The best physical properties of the soil were found at the surface level of $0-10 \mathrm{~cm}$, which is a positive feature of the soil. At this level, the highest average value of MWD and POR and related PAW and $\mathrm{K}$ parameters were recorded. The values of individual parameters are $1.7 \mathrm{~mm}$ and $50 \%$ as well as $0.22 \mathrm{~m}^{3} \cdot \mathrm{m}^{-3}$ and $240 \mathrm{~cm} \cdot \mathrm{d}^{-1}$, respectively. At the surface level, the lowest mean $\mathrm{BD}$ value was also noted $\left(1.23 \mathrm{~g} \cdot \mathrm{cm}^{-3}\right)$. Bulk density or total porosity can be determined much more easily than the water retention curve (Vizitiu et al. 2011). The worst soil properties were found at the level of 40-60 cm. For this level, the lowest values of MWD and POR were recorded $-1.4 \mathrm{~mm}$ and $37 \%$, respectively (Table 2 ). The lowest PAW content $\left(0.13 \mathrm{~m}^{3} \cdot \mathrm{m}^{-3}\right)$ and $\mathrm{K}$ value $\left(50 \mathrm{~cm} \cdot \mathrm{d}^{-1}\right)$ were also recorded, and the highest $\mathrm{BD}$ value $\left(1.68 \mathrm{~g} \cdot \mathrm{cm}^{-3}\right)$. This is reflected in the SPQI values.

The values of the Pearson correlation coefficient between the analysed soil physical quality indexes are presented in Table 3. The correlation coefficient indicates very high dependencies in the case of most parameters. A very high negative correlation $(r>0.8)$ was found between the values of BD and MWD, K, POR and PAW. These parameters are most often used to monitor the physical quality and soil assessment (Asgarzadeh et al.
2010, Paluszek 2011, Moncada et al. 2014). The highest positive correlation with other parameters was found for porosity ( $r>0.9)$. Very low or negligible correlation was found for the $\mathrm{S}$.

Most soil physical parameters except for BD and $\mathrm{S}$ characteristics were similar in the whole soil profile $0-60 \mathrm{~cm}$ (Table 4). The surface soil horizon $0-10 \mathrm{~cm}$ had much better soil parameters (lower BD, and higher PAW, K, POR and MWD) compared to the horizons in other depths. The impacts of all physical parameters on soil quality in four soil depths were calculated by means of the indexing method.

The SPQI analysis includes nine soil quality indicators that have been integrated after the assessment. The basis for the information was mainly available literature, and in some cases the opinion of the authors was used (Table 1). In addition, various studies used different scoring of the same indicator depending on the type of soil and method of use. High variability in parameter values (Table 2) has not always been reflected in the index values. There were no statistically significant differences $(p=0.05)$ between the test points (Table 3 ). Statistically significant differences were found between soil horizons. SPQI significantly lowered on the horizon $0-10 \mathrm{~cm}$ to horizon $40-60 \mathrm{~cm}$, indicating that the quality of the soil was influenced by the depth of sampling. The SPQI value calculated for the 0-60 cm layer Technosol was 0.51 , which indicates good soil parameters. The average SPQI values obtained from calculations for each depth are shown in Figure 1. SPQI estimated from nine different physical parameters was validated with wood production by calculating correlation coefficients. Pearson correlation coefficients calculated for the soil physical quality index (SPQI) and averaged for a given depth are statistically significant.

Table 3. Pearson correlation coefficients of soil physical parameters

\begin{tabular}{|l|c|c|c|c|c|c|c|c|}
\hline \multicolumn{1}{|c|}{ Variables } & BD & MWD & AWC & K & POR & PAW & Stl & S \\
\hline sand & $-0.81^{*}$ & $0.93^{*}$ & 0.42 & $0.88^{*}$ & $0.93^{*}$ & $0.84^{*}$ & 0.44 & 0.19 \\
\hline BD & & $-0.90^{*}$ & -0.41 & $-0.99^{*}$ & $-0.96^{*}$ & $-0.83^{*}$ & $-0.60^{*}$ & $-0.73^{*}$ \\
\hline MWD & & & 0.17 & $0.96^{*}$ & $0.91^{*}$ & 0.71 & 0.29 & 0.42 \\
\hline AWC & & & & 0.34 & $0.54^{*}$ & $0.81^{*}$ & $0.95^{*}$ & 0.19 \\
\hline K & & & & & $0.97^{*}$ & $0.81^{*}$ & $0.51^{*}$ & $0.63^{*}$ \\
\hline POR & & & & & & $0.93^{*}$ & $0.66^{*}$ & $0.52^{*}$ \\
\hline PAW & & & & & & & $0.86^{*}$ & 0.41 \\
\hline Stl & & & & & & & & 0.49 \\
\hline
\end{tabular}

* Coefficients significant at $\mathrm{P}<0.05$ 
Table 4. Soil indicators scores

\begin{tabular}{|l|c|c|c|c|c|}
\hline \multicolumn{1}{|c|}{ Indicators } & unit & $0-10$ & $10-20$ & $20-40$ & $40-60$ \\
\hline Texture & - & 4 & 3 & 3 & 3 \\
\hline BD & $\mathrm{Mg} \cdot \mathrm{m}^{-3}$ & 3 & 2 & 0 & 0 \\
\hline MWD & $\mathrm{mm}$ & 2 & 2 & 2 & 2 \\
\hline AWC & $\mathrm{m}^{3} \cdot \mathrm{m}^{-3}$ & 3 & 3 & 3 & 2 \\
\hline K & ${\mathrm{cm} \cdot \mathrm{d}^{-1}}^{3}$ & 2 & 2 & 2 & 3 \\
\hline POR & $\%$ & 4 & 4 & 3 & 2 \\
\hline PAW & $\%$ & 4 & 4 & 0 & 0 \\
\hline Stl & - & 0 & 0 & 0 & 1 \\
\hline S & & 2 & 2 & 17 & 15 \\
\hline Total & & 24 & 22 & 3 & \\
\hline
\end{tabular}

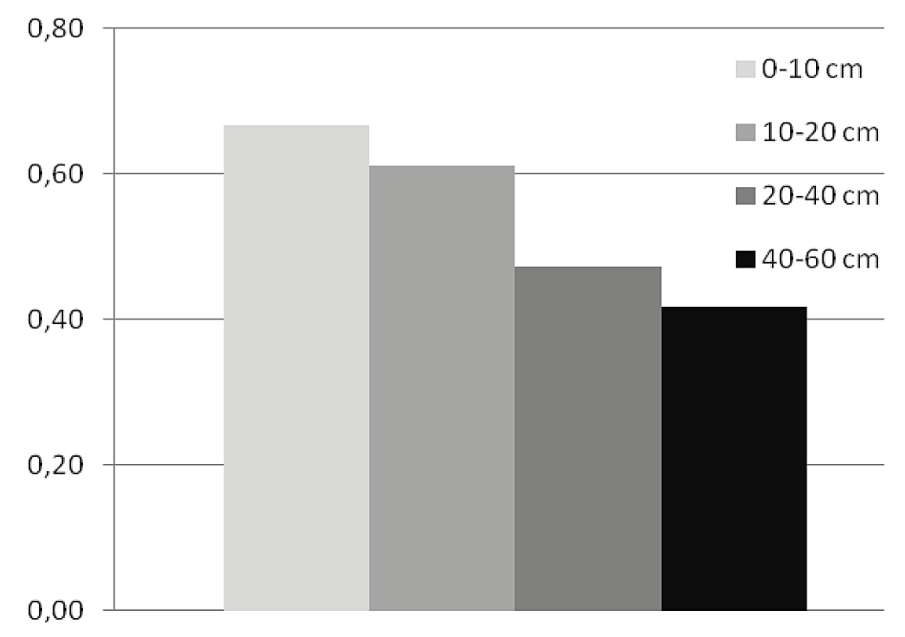

Figure 1. Overall soil physical quality index (SPQI) values

\section{CONCLUSIONS}

The results of the research indicate that all nine parameters can be used in an analysis and evaluation of the soil physical quality. The studied heap of sloping area is characterized by medium soils of the types most suitable for growing forest. Reclamation and proper management of degraded areas plays an important role in water retention. Increasing the area of green areas counteracts the climate change. The soil quality can be assessed based on the individual soil properties. However, integrated soil quality indicator provides a more holistic assessment. Field soil tests were carried out in the agricultural season of 2018 in the coal mine spoil depends. It was the first time when the most often used physical properties were employed to determine the soil quality index. The proposed solution for determining the soil quality in the environment can be important in terms of establishing the degree of soil degradation. For the research, the horizon surface soil has better soil quality indicators than the horizon underground soils. The SPQI value is affected by the type and depth of soil sampling. SPQI calculated using the method is relatively easy and user-friendly. The advantage of using SPQI to assess the soil quality is that this parameter can be assessed by measuring any number of soil parameters. The presented procedure is easier to use compared to other methods because the scoring only requires a review of the literature. The disadvantage of SPQI is that it is subjective as it is based on the opinion of the authors.

\section{REFERENCES}

1. Albaladejo J., Ortiz R., García-Franco N., RuízNavarro A., Almagro M., García-Pintado J., Martínez-Mena M., 2013. Land-use and climate change impacts on soil organic carbon stocks in semi-arid Spain. J. Soils Sediments 13, 265-277. 
2. Aimrun W., Amin M.S.M., Eltaib S.M., 2004. Effective porosity of paddy soils as an estimation of its saturated hydraulic conductivity. Geoderma 121(3-4), 197-203.

3. Amacher M.C., Perry C.H., 2007. Soil vital signs: a new soil quality index (SQI) for assessing forest soil health. Res. Pap. RMRS-RP-65WWW. Fort Collins, CO: U.S. Department of Agriculture, Forest Service, Rocky Mountain Research Station. 12 p.

4. Andrews S.S., Carroll C.R., 2001. Designing a soil quality assessment tool for sustainable agroecosystem management. Ecol. Appl. 11, 1573-1585.

5. Andrews S.S., Karlen D.L., Cambardella C.A., 2004. The soil management assessment framework: a quantitative soil quality evaluation method. Soil Sci. Soc. Am. J. 68, 1945-1962.

6. Armenise E., Redmile-Gordon M.A., Stellacci A.M., Ciccarese A., Rubino P., 2013. Developing a soil quality index to compare soil fitness for agricultural use under different managements in the Mediterranean environment. Soil Till. Res. 130, 91-98.

7. Asensio V., Guala S.D., Vega F.A., Covelo E.F., 2013. A soil quality index for reclaimed mine soils, environ. Toxicol. Chem. 32, 2240-2248.

8. Asgarzadeh H., Mosaddeghi M.R., Mahboubi A.A., Nosrati A., Dexter A.R., 2010. Soil water availability for plants as quantified by convention available water, least limiting water range and integral water capacity. Plant soil 335, 229-240.

9. Barthès B., Roose E., 2002. Aggregate stability as an indicator of soil susceptibility to runoff and erosion; validation at several levels. Catena 47, 133-149.

10. Bastida F., Zsolnay A., Hernandez T., Garcia C., 2008. Past, present and future of soil quality indices: a biological perspective. Geoderma 147, 159-171.

11. Borchulski Z., Grudzińska A., Łyszczarz L., Święs F., 1994. Koncepcja rekultywacji biologicznej odpadów pogórniczych KWK „Bogdanka”. Bezpieczeństwo pracy i ochrona środowiska w górnictwie. Kwartalnik Wyższego Urzędu Górniczego 3(11), 5-9.

12. Borek Ł. 2019. The use of different indicators to evaluate chernozems fluvisols physical quality in the Odra River valley: a case study. Pol. J. Environ. Stud. 28 (6), 4109-4116.

13. Cherubin M.R.,. Karlen D.L., Franco A.L.C., Tormena C.A., Cerri C.E.P., Davies C.A., Cerri C.C., 2016. Soil physical quality response to sugarcane expansion in Brazil. Geoderma 267, 156-170.

14. Ciosmak M., Grzywna A., Bochniak A. 2017. The effect of hard coal mine drainage water on the quality of surface and ground waters. Rocznik Ochrona Środowiska, 19, 411-422.

15. Czyż E.A., 2004. Effects of traffic on soil aeration, bulk density and growth of spring barley. Soil Till. Res. 79, 153-166.
16. Dexter A.R., Czyż E.A., 2007. Applications of Stheory in the study of soil physical degradation and its consequences. Land degradation \& development 18, 369-380.

17. Drewry J.J., Cameron K.C., Buchan G.D., 2008. Pasture yield and soil physical property responses to soil compaction from treading and grazing: a review. Aust. J. Soil Res. 46, 237-249.

18. Dwevedi A., Kumar P., Kumar P., Kumar Y., Sharma Y.S., Kayastha A.M. 2017. Soil sensors: detailed insight into research updates, significance, and future prospects. Chapter in new pesticides and soil sensors. Academic press 561-590.

19. Feiza V., Feiziene D., Kadziene G., Lazauskas S., Deveikyte I., Slepetiene A., Seibutis V., 2011. Soil state in the 11th year of three tillage systems application on a Cambisol. Journal of Food, Agriculture and Environment 9, 1088-1095.

20. Gazda L., Oleszczyński B., 1988. Charakterystyka mineralogiczno-chemiczna oraz analiza możliwości wykorzystania przeróbczych odpadów przywęglowych z kopalni w Bogdance. Przegląd Górniczy 44(11-12), 16-18.

21. Girmay G., Singh B.R., 2012. Changes in soil organic carbon stocks and soil quality: Land-use system effects in northern Ethiopia. Acta Agric. Scand. B 62, 519-530.

22. Głąb T., Kulig B., 2008. Effect of mulch and tillage system on soil porosity under wheat (Triticum aestivum). Soil Till. Res., 99, 169-178.

23. Hamza M.A., Anderson W.K., 2005. Soil compaction in cropping systems. A review of nature, causes and possible solutions. Soil Till. Res. 82, 121-130.

24. Imaz M.J., Virto I., Bescansa P., Enrique A., Fernandez-Ugalde O., Karlen D.L., 2010. Soil quality indicator response to tillage and residue management on semi-arid Mediterranean cropland. Soil Till. Res. 107, 17-25.

25. Iwanek M., 2008. A method for measuring saturated hydraulic conductivity in anisotropic soils. Soil Sci. Soc. Am. J., 72, 1527-1531.

26. Karlen D.L., Andrews S.S., Doran J.W., 2001. Soil quality: current concepts and applications. Advances in agronomy. Academic press $1-40$.

27. Kondracki J., 2001. Geografia regionalna Polski. PWN Warszawa.

28. Lal R., 1994. Methods and guidelines for assessing sustainable use of soil and water resources in the tropics. Washington D.C.: USDA/SMSS Technical monograph 21.

29. Lipiec J., Walczak R., Witkowska-Walczak B., Nosalewicz A., Słowińska-Jurkiewicz A., Sławiński C., 2007. The effect of aggregate size on water retention and pore structure of two silt loam soils of different genesis. Soil Till. Res. 97, 239-246. 
30. Masto R.E., Chhonkar P.K., Singh D., Patra A.K., 2008. Alternative soil quality indices for evaluating the effect of intensive cropping, fertilisation and manuring for 31 years in the semi-arid soils of India. Environmental Monitoring and Assessment 136, 419-435.

31. Masto R.E., Sheik S., Nehru G., Selvi V.A., George J., Ram L.C., 2015. Environmental soil quality index and indicators for a coal mining soil. Solid Earth Discuss. 7, 617-638.

32. Mohanty B.P., Mousli Z., 2000. Saturated hydraulic conductivity and soil water retention properties across a soil-slope transition. Water Resources Res. 36, 3311-3324.

33. Moncada M.P., Ball B.C., Gabriels D., Lobo D., Cornelis W.M., 2015. Evaluation of soil physical quality index s for some tropical and temperate medium-textured soils. Soil Sci. Soc. Am. J. 79, 9-20.

34. Moncada M.P., Penning L.H., Timm L.C., Gabriels D., Cornelis W.M., 2014. Visual examinations and soil physical and hydraulic properties for assessing soil structural quality of soils with contrasting textures and land uses. Soil Till. Res. 140, 20-32.

35. Mukherjee A., Lal R., 2014. Comparison of soil quality index using three methods. Plos one 9(8), e105981. Doi:10.1371/journal.pone.0105981

36. Mukhopadhyay S., Masto R.E., Yadav A., George J., Ram L.C., Shukla S.P., 2016. Soil quality index for evaluation of reclaimed coal mine spoil. Science of the Total Environment 542, Part A, 40-550.

37. Muršec M., Leveque J., Chaussod R., Curmi P., 2018. The impact of drip irrigation on soil quality in sloping orchards developed on marl - a case study. Plant, soil environ 64, 20.

38. Nabayi A., Girei A. H., Abubakar M. S., 2019. Physical and hydraulic properties of soils under a long-term tillage practices in Hadejia Local Government Area, Jigawa State, Nigeria. Eurasian Journal of Soil Science 8, 267-274.

39. Nakajima T., Lal R., Jiang S., 2015. Soil quality index of a Crosby silt loam in central Ohio. Soil Till. Res. 146, 323-328.

40. Paluszek J., 2011. Kryteria oceny jakości fizycznej gleb uprawnych Polski. Acta Agrophysica, Rozprawy i monografie 191.

41. Pieri C.J.M.G., 1992. fertility of soils: a future for farming in the west African savannah. SpringerVerlag. Berlin, Germany.

42. Reynolds W.D., Drury C.F., Tan C.S., Fox C.A., Yang X.M., 2009. Use of indicators and pore volume-function characteristics to quantify soil physical quality. Geoderma 152, 252.

43. Reynolds W.D., Drury C.F., Yang X.M., Tan C.S.,
2008. Optimal soil physical quality inferred through structural regression and parameter interaction. Geoderma 146, 466-474.

44. Salehi A., Malek M., 2012. Evaluation of soil physical and chemical properties in poplar plantations in north of Iran. Ecologia Balkanica 4(2), 69-76

45. Shukla M.K., Lal R., Ebinger M., 2006. Determining soil quality indicators by factor analysis. Soil Till. Res. 87, 194-204.

46. Singh M.J., Khera K.L., 2009. Physical indicators of soil quality in relation to soil erodibility under different land use. Arid Land Res. Manag. 23, 152-167.

47. Święs F., Kwiatkowska-Farbiś M., 1996. Szata roślinna na hałdzie skały płonnej przy kopalni węgla kamiennego „Bogdanka” S.A. (Lubelskie Zagłębie Węglowe). Ann. Univ. Mariae Curie-Skłodowska C, 51, 41-58.

48. Tárník A., Leitmanová M., 2017. Analysis of the development of available soil water storage in the Nitra river catchment. IOP Conf. Series: Materials Science and Engineering 245-256.

49. Touil S., Degré A., Chabaca M.N., 2016. Sensitivity analysis of point and parametric pedotransfer functions for estimating water retention of soils in Algeria. Soil 2, 647.

50. Turski R., Baran S., Kwiecień I., 1991. Możliwość rolniczego zagospodarowania odpadów górniczych z KWK „Bogdanka”. Ann. Univ. Mariae CurieSkłodowska E, 46, 149-153.

51. Vizitiu O., Calciu I., Pănoiu I., Simota C., 2011. Soil physical quality as quantified by $\mathrm{S}$ index and hidrophysical indices of some soils from agree hydrographic basin. Research Journal of Agricultural Science 43, 249-261.

52. WRB: World reference base for soil resources, 2014. International soil classification system for naming soils and creating legends for soil maps. Rome: FAO, World Soil Resources Reports No. 106.

53. Zobeck T.M., Steiner J.L., Stott D.E., Duke S.E., Starks P.J., Moriasi D.N.,. Karlen D.L., 2015. Soil quality index comparisons using Fort Cobb, Oklahoma, watershed-scale land management data. Soil Sci. Soc. Am. J. 79, 224-238.

54. Zornoza R., Mataiz-Solera J., Guerrero J., Arcenegui V., García-Orenes F., Mataix-Beneyto J., Morugán A., 2007. Evaluation of soil quality using multiple lineal regression based on physical, chemical and biochemical properties. Sci. Total Environ. 378, 233-237.

55. Zornoza R., Acosta J. A., Bastida F., Domínguez S. G., Toledo D. M., Faz A., 2015. Identification of sensitive indicators to assess the inter relationship between soil quality, management practices and human health. Soil 1, 173-185. 